\title{
Hyvää ja pahaa tietoa
}

Ilari Hetemäki, Anna-Kaisa Kuusisto, Maria Lähteenmäki \& Esa Väliverronen (toim.) (2021). Hyvä ja paha tieto. Gaudeamus. 304 sivua.

RAAMATUNKERTOMUKSESSA hyvän ja pahan tiedon puusta samoin kuin antiikin Prometheusmyytissä ja myöhemmässä Fausttarinassa pohditaan, onko tietäminen ihmiselle ylipäätään hyväksi. Jo antiikin aikana ja keskiaikaisissa kansantarinoissa kerrottiin sielunsa paholaiselle myyneestä miehestä. Myöhempi Faust-aihe pohjautuu historiallisen henkilön, vuonna 1540 kuolleen okkultistin ja astrologin, tohtori Johann Faustin elämään. Aihetta kyltymättömän tiedonjanon hinnasta hyödynsivät kirjailijat Christopher Marlowe, Johann Wolfgang von Goethe, Thomas Mann sekä useat säveltäjät.

Akateemikko Georg Henrik von Wright (1916-2003) kritisoi länsimaista kyltymätöntä teknologista kulttuuria ja varoitti kasvihuoneilmiöstä jo 1980-luvun puolivälissä. Tieto on valtaa suhteessa toisiin ihmisiin, mutta myös luontoon. Hyvä ja paha tieto -teoksessa von Wrightistä kirjoittaa Bernt Österman ja Faust-aiheesta H. K. Riikonen.

Tieteen päivien esityksiin pohjautuva julkaisu sisältää 18 eri alojen artikkelia ja 22 niin sanottua kainalojuttua, teemoihin linkittyvää lyhyttä kirjoitusta. Kirjan ensimmäisessä osassa "Vaiettu ja vaikea tieto" tarkastellaan moniaineksisesti "tietoa, järkeä, yhteiskunnan järjestymistä, elettyjä ko- kemuksia ja oppimista erilaisissa ajallisissa ja tilallisissa yhteyksissä". Toinen osa "Tutkittu tieto mediassa ja päätöksenteossa" tarjoaa näkemyksiä tieteellisen tiedon julkisen esittämisen areenoista ja tutkimustiedon merkityksestä yhteiskuntaa ohjaavien päätösten taustalla. Kolmannessa osassa "Tieto tulevaisuudesta" pohditaan digitaalisten paikannus- ja algoritmiteknologioiden sovellusten eettisyyttä ja planeetan elinkelpoisuuden ja luonnon monimuotoisuuden kysymyksiä.

\section{HILJAISUUDEN KULTTUURI}

Lasten ruumiillinen kuritus kiellettiin rikosoikeudellisena rangaistuksena vuonna 1943, lastenkodeissa 1950-luvulla ja koulukodeissa vuonna 1965, mutta vanhempien oikeus kurittaa lastaan poistui vasta vuonna 1985. Professori Pirjo Markkola kuvaa auttamisen ja tukemisen kääntöpuolta, lastensuojelun epäonnistumisten historiaa, jota Suomi selvitti viimeisenä Pohjoismaana. Lastensuojelun menneisyysselvityksen mukaan väkivalta oli usein rakenteellista, ja lasten oli vaikea hahmottaa, mistä heitä milloinkin rangaistiin. On viitteitä siitä, että ainakin osa ongelmista oli aikanaan viranomaisten tiedossa. Väkivaltaa kokeneille

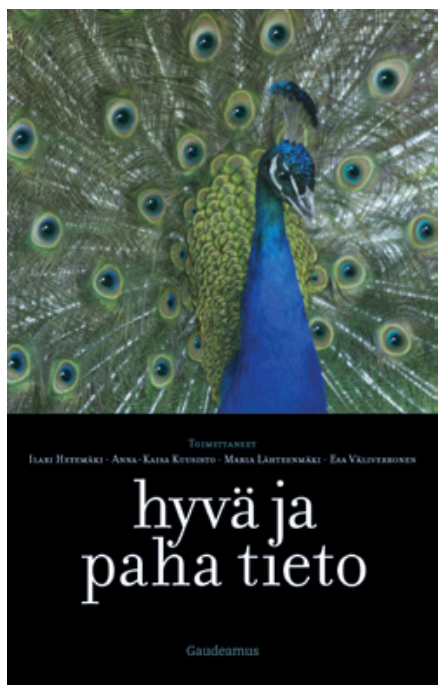

esitettiin vuonna 2016 valtiovallan anteeksipyyntö.

Dosentti Eerika Koskinen-Koivisto kirjoittaa toiseen maailmansotaan kytkeytyvästä hiljaisuuden kulttuurista. Puhumattomuutta synnyttää paitsi selviytymisen pakko, myös vakaumus, että menneet unohtamalla on mahdollisuus päästä eteenpäin. Lasten on pitänyt kannatella kovia kokeneita vanhempiaan. Sotalapset joutuivat häpeämään taustaansa Ruotsiin ja jälleen takaisin Suomeen siirtyessään.

Ruotsissa lasten tilannetta ei helpottanut maassa laajalle levinnyt käsitys siitä, että suomalaiset olivat useiden muiden ryhmien ohella alempaa rodullista aineista kuin puhdasta arjalaisuutta edustavat ruotsalaiset. Vuoden 1918 sisällissodan jälkitunnelmissa suomenruotsalainen lääkäri ja kansanedustaja Georg von Wendt varoitti sekarotuisuuden pohjustavan bolševismia. Tätä synkkää historiaa valaisee kirjassa historioitsija Meri-Arni Kauttu. 


\section{MoninaisuUs TeKeE Tieteellisestä}

TIEDOSTA PAREMPAA.

\section{KASVATUSTIETO}

Suomen koulutuspoliittinen linja on pitkään poikennut talousjärjestö OECD:n suosittelemasta suoraviivaisesta uusliberalismista, mutta huolenaiheitakin on. Valtion osuus perusopetuksen järjestämiskustannuksista oli 1990-luvun lopulla 60 prosenttia, sittemmin se on puolittunut. Pulkkinen katsoo, että oppivelvollisuusiän nostaminen ilman tutkimusta voi lisätä syrjäytymistä ja kärjistää muita ongelmia. Ammatillisen koulutuksen resurssit ovat romahtaneet, ja lukiot ovat kaventuneet kirjoituksiin valmistaviksi hikipajoiksi. Lukio antaa liian vähän vapautta, ammatillinen koulutus liian vähän tukea.

Kasvatusfilosofi Gert Biestan mukaan koulun ei tulisi olla oppilas- tai opetussuunnitelmakeskeinen vaan maailmakeskeinen. Koulujärjestelmän uudistukset eivät ole perustuneet tutkimustietoon tai kasvatusfilosofiaan. Emeritaprofessori Liisa Keltikangas-Järvisen mukaan osa lapsista putoaa alisuoriutujiksi uudenaikaisessa kouluympäristössä, jota ylistetään siitä, että "ei enää tunnista tulleensa kouluun". Vaihtuvat opettajat ja oppilasryhmät jättävät oppilaan ilman tukea.

\section{TIEDE JA ASIANTUNTIJATIETO}

Professori Esa Väliverrosen mukaan ei voi suoraan väittää, että koronakriisi olisi lisännyt luotta- musta tieteeseen ja asiantuntijoihin. Kun asiantuntijuus rakentuu modernissa yhteiskunnassa tieteen ja instituutioiden varaan, myöhäismodernissa yhteiskunnassa näitä kyseenalaistetaan jatkuvasti. Vaikka tukeutuminen yhteiskunnan instituutioihin kriisioloissa yleisesti lisääntyy, samalla tiedettä politisoidaan ja asiantuntijatietoa korvataan salaliittoteorioilla. Asiantuntijan statukseen voi riittää hyvä itsensä brändääminen. Tutkimuksen keinoin todennettuja faktoja tärkeämpää on hyvin esitetty tarina.

Kun uutta tietoa on kriisioloissa saatava nopeasti, ilmestyy suuria määriä ennakkojulkaisuja, preprinttejä, jotka eivät vielä ole käyneet läpi tieteellistä vertaisarviointia. Puheet asiantuntijuuden kuolemasta ovat Väliverrosen mukaan kuitenkin liioiteltuja.

Talouspoliittisessa keskustelussa esitetään tutkimuspohjaisina totuuksina väitteitä, zombiajatuksia, joiden yhteys tutkimukseen on aikaa sitten katkennut. Tiede ei professori Petri Ylikosken mukaan ole ideologioista vapaata, koska keskustelu tieteen yhteiskunnallisesta tehtävästä on ideologista. Sen sijaan, että haaveilemme ideologiavapaasta tieteestä, tulisi pohtia, kuinka ideologioita käsitellään tieteessä. Ylikoski pitää epistemologisesti kiinnostavana ajatuksena sitä, että moninaisuus tekee tieteellisestä tiedosta parempaa ja luotettavampaa.

\section{KIMALAISTEN ÄLYKKYYS}

Vaikka kirjan nimi, Hyvä ja paha tieto, johdattaa lukijan ajatuksen eri alojen eettisiin kysymyksiin, etiikkaa ei teoksessa kovinkaan paljon käsitellä lukuun ottamatta yksittäisiä mainintoja esimerkiksi genomihankkeista ja algoritmisovelluksista kerrottaessa.

Tähtitieteen tutkija Marianna Ridderstadin mukaan tiede, uskonto ja politiikka ovat suurimman osan historiaansa olleet yhtä ja samaa käytännön elämän tarpeiden muokkaamaa maailmankuvaa. Aineellisen ja aineettoman, yksilön ja yhteisön, julkisen ja yksityisen sekä vallan ja voimattomuuden rajat ovat olleet joustavammat kuin nykyisin. Lukija jää toivomaan enemmänkin tiedonarkeologista pohdintaa siitä, mitä kaikkea hyvä ja paha tieto on ollut historian eri vaiheissa.

Kirjan loppuosan artikkeleista voi kyllä päätellä, että tämän ajan paha tieto on muiden selän taakse piiloutuvaa, väärällä tavalla ihmiskeskeistä, luontoa välineellistävää ja monimuotoisuutta ymmärtämätöntä. Merentutkija Otto Latvan mukaan luonto muuttui 1500-1600-lukujen vaihteessa materiaksi, jota oli helppo riistää. Eläimistä tuli toiminnan kohteita ja riistaa. 1700-luvulla Carl von Linnén kattava luokittelujärjestelmä vahvisti käsitystä luonnon historiattomuudesta evoluutioteoriasta huolimatta. Kuluneiden 
viiden vuosikymmenen aikana olemme onnistuneet hävittämään noin seitsemän kymmenestä maailmassa eläneestä nisäkkäästä, linnusta, matelijasta, sammakkoeläimestä ja kalasta. Yli kolmannes maapallon maapinta-alasta on valjastettu lihan tuotantoon. Vastuunsiirto voi estää organisaatioita kehittämästä toimintaansa nykyistä ympäristöystävällisemmäksi, mitä voi professori Janne S. Kotiahon mukaan nimittää EMMIilmiöksi: "En minä, mutta muut".
Professori Arto O. Salonen pitää huolenpitoa eettisenä kysymyksenä. Ilman toisen asemaan asettumista myötätuntoista suhdetta ei synny. Emme esimerkiksi osaa pitää sosiaalisesti oppivia kimalaisia älykkäinä niiden seesaminsiemenen kokoisten aivojen vuoksi kuten eläintieteen dosentti Olli Loukola sanoo.

\section{JUSSI ONNISMAA}

FT, dosentti, työnohjaajakouluttaja, tietokirjailija

\section{LISÄÄ AIHEESTA}

Onnismaa, J. (2020). "Filosofi isolla F:llä, vaikka asuukin Suomessa": Johan Strang \& Thomas Wallgren (toim.) Georg Henrik von Wright, modernin ajan ajattelija. Suom. Timo Soukola. Gaudeamus 2020. 349 sivua. Aikuiskasvatus, 40(2), 152-153. https://doi.org/10.33336/ aik.95457

\section{Sukella digiarkistoon}

Aikuiskasvatus-tiedelehti on digitoitu koko julkaisuhistorialtaan, vuodesta 1981 lähtien. Kaikki numerot ovat ilmaiseksi luettavissa Journal.fi-palvelussa. 